\title{
Investigations of Sedative and Antidiarrheal Activity of Commelina appendiculata in Swiss Albino Mice
}

\author{
Pritesh Ranjan Dash ${ }^{1, a^{*}}$, Md. Sohel Rana ${ }^{1, b}$ and Mohammad Shawkat Ali ${ }^{2, c}$ \\ ${ }^{1}$ Department of Pharmacy, Jahangirnagar University, Savar, Dhaka, Bangladesh \\ ${ }^{2}$ Department of Clinical Pharmacy and Pharmacology, University of Dhaka, Dhaka, \\ Bangladesh
}

apritesh.ju@gmail.com, bprofdr.sohelrana.ju@gmail.com, cprofdr.shawkat@gmail.com

\begin{abstract}
Keywords: Commelina appendiculata, thiopental sodium induced sleeping time test, hole cross test, open field test, castor oil, magnesium sulphate.
\end{abstract}

\begin{abstract}
The aim of the present study was to investigate the sedative and antidiarrheal activity of ethanol extract of C. appendiculata at the doses of 100 and $200 \mathrm{mg} / \mathrm{kg}$ body weight per oral (p.o) in Swiss albino mice. Sedative activity of the extract (100 and $200 \mathrm{mg} / \mathrm{kg}$, p.o.) was assessed utilizing thiopental sodium-induced sleeping time model to evaluate sedative potential of the extract, hole cross to evaluate motor activity and open field test to evaluate exploratory behaviour. The extract also produced rapid onset and maximized the duration of sleeping time when administered with thiopental sodium. The extract fundamentally $(\mathrm{p}<0.05-0.001)$ diminished motor action and exploratory conduct of mice in hole cross and open field test separately. In antidiarreal activity study, the concentrate $(200 \mathrm{mg} / \mathrm{kg})$ likewise demonstrated most extreme inhibition of defecation $(90.64 \%$ and $80.95 \%)$ in both models individually. The present study demonstrates that the ethanol extract of $C$. appendiculata have central nervous system (CNS) depressant and antidiarrheal properties. In this manner, the plant may be further investigated to find for its pharmacological active natural products.
\end{abstract}

\section{Introduction}

Commelina appendiculata (C.appendiculata) locally called as Kanda Loa, under the family of commelinaceae is an annual herb distributed in Eastern India and Sri Lanka. In Bangladesh, it occurs in Tangail, Mymensingh and Sylhet district. It is used in the Sunamganj district as a folk medicine for the treatment of cats, dogs and snake bites [1]. A portion of the type of Commelina are utilized in Chinese medicine for the treatment of wind-heat type common cold, sore throat, fever and dropsy [2]. For instance, C. communis L., a species of the Commelina genus, widespread in the world especially in the tropics and subtropics, has long been used in folk medicine in China, and modern pharmaceutical investigations has revealed its anti-inflammatory, antiviral, and antihyperglycemic effects [3]. It has been reported that many plants of this genus are used in medicine for the treatment of inflammation, pain, fever, dysentery, diarrhea, neurological disorders, cancer, toxicity, heart diseases, asthma, oxidative stress etc $[3,4]$. The plant is accounted for to have pain relieving and cytotoxic action [5]. Past phytochemical examinations of the Commelina genus were accounted for on C. undulata R.Br., C. benghalensis L. furthermore, C. communis L. from which a few sorts of compounds, for example, alkaloids, steroids, terpenoids, iridoids, flavonoids, lignans, aliphatic alcohols, polyols, and phenolic acids were obtained [6-14]. Moreover, the plant of $C$. appendiculata was reported to contain carbohydrates, tannins, flavonoids, glycoside and alkaloids [5]. Literatures survey revealed no previous report on the sedative and antidiarrheal activity of $C$. appendiculata. Subsequently, as a piece of our proceeding with studies $[5,15]$ on characteristic items for their pharmacological properties interestingly we explored the ethanolic extract of $C$. appendiculata for its sedative and antidiarrheal activity. 


\section{Materials and Methods}

\section{Collection of the Plant}

The plant of $C$. appendiculata was gathered from neighborhood Sylhet sadar in January 2014. The gathered plant was then recognized by the taxonomist of Jahangirnagar University Herbarium, Savar and a voucher example has been kept (DACB: 39,321) for further reference.

\section{Extraction of the Plant Material}

After shade drying, the entire plant was decreased to coarsely powder utilizing a grinding mill. The plant was extracted by a cold extraction strategy. The dried and coarse powder (106 g) was extracted with ethanol $(500 \mathrm{ml})$ in an air proof, clean level bottomed holder for 3 days at room temperature with incidental mixing. The extract was then separated by filtration and evaporated using rotary evaporator under reduced pressure to got $18 \mathrm{gm}$ (yield $=16.98 \%$ ) crude extract which was utilized for conducting the study regarding sedative and antidiarrheal activity.

\section{Chemicals}

Magnesium sulfate (Merck, Germany), castor oil (Well's Health Care, Spain).Diazepam and Loperamide (Square Pharmaceuticals Ltd., Bangladesh), thiopental sodium (Gonoshasthaya Pharmaceuticals Ltd., Bangladesh) Normal saline arrangement (Orion Infusion Ltd., Bangladesh), were acquired and utilized as a part of the examination. All chemicals in this examination were of analytical reagent grade.

\section{Animals}

Swiss albino mice of either sex, 3-4 weeks of age, weighing between 25-30 gm were utilized for as a part of vivo pharmacological screening. Mice were gathered from the animal research branch of the International Center for Diarrhoeal Disease and Research, Bangladesh (ICDDR, B). They were housed in standard ecological conditions and sustained with rat eating routine and water not indispensable. The departmental animal look into moral board of trustees endorsed the test convention.

\section{Drugs and Treatment}

After reconstituted in distilled water the extract was controlled to the mice at 100 and $200 \mathrm{mg} / \mathrm{kg}$ per orally by gavage. The water $(5 \mathrm{ml} / \mathrm{kg})$ was controlled by gavage to control group. All medications, utilized as standard, were dissolved in $0.9 \%$ saline and directed intraperitoneally (i.p). Diazepam $(2 \mathrm{mg} / \mathrm{kg}$ i.p) and Loperamide $(3 \mathrm{mg} / \mathrm{kg})$ were utilized as standard CNS depressant and antidiarrheal sedate, separately.

\section{Acute Toxicity Study}

Mice were isolated into control and test bunches $(n=6)$. Diverse measurements of plant concentrates up to $2000 \mathrm{mg} / \mathrm{kg}$, p.o. was managed and test animals were watched for the initial 3 hours of administration and mortality rate was determined within 72 hours [16].

\section{Neuropharmacological Activity}

\section{Thiopental Sodium Induced Sleeping Time Test}

The animals were haphazardly partitioned into four gatherings comprising of six mice each. The test groups got of $C$. appendiculata extracts at the measurements of 200 and $400 \mathrm{mg} / \mathrm{kg}$ while positive control was treated with diazepam $(2 \mathrm{mg} / \mathrm{kg}$ i.p. $)$ and control with water. After thirty minutes, pentobarbitone $(40 \mathrm{mg} / \mathrm{kg}$, i.p.,) was regulated to every mouse to actuate rest. The animals were watched for the time between pentobarbitone administration to loss of correcting reflex and term of time between the loss and recuperation of correcting reflex [17]. Rate of effect in percentage was computed utilizing the following formula: 


$$
\text { Effect }(\%)=\frac{\text { Average duration of loss of righting reflex in the test group }}{\text { Average duration of loss of righting reflex in the control group }} \times 100
$$

\section{Hole Cross Test}

The most solid behavioural change is a hyperemotional reaction to novel ecological. The technique was embraced as depicted by Takagi et al. [18]. The point of this study was to describe the passionate conduct of rodents utilizing the hole cross test. The quantity of section of a mouse through the gap from one chamber to the next was meant a time of $3 \mathrm{~min}$ at $0,30,60,90$ and $120 \mathrm{~min}$ after oral administration of standard Diazepam $(2 \mathrm{mg} / \mathrm{kg})$ and ethanol separate at measurements of 100 and $200 \mathrm{mg} / \mathrm{kg}$ body weight. Percentage inhibition of movements was computed utilizing the following equation:

$$
\text { Movements inhibition (\%) }=\frac{\text { Mean No. of movements (control) }- \text { Mean No. of movements (test) }}{\text { Mean No. of movements (control) }} \times 100
$$

\section{Open Field Test}

This investigation additionally assesses a range of anxiety-induced, locomotor activity and exploratory activities of rodents. The animals were dealt with as the past expressed way and at same dosages. The test was performed by procedure portrayed by Gupta et al. [19]. The quantity of squares went by the animals was computed for $3 \mathrm{~min}$, at $0,30,60,90$ and 120 min ensuing to oral administration of the test crude extracts. Percentage inhibition of movements was computed utilizing a similar formula utilized as a part of hole cross test.

\section{Antidiarrheal Activity}

\section{Castor Oil Induced Diarrhea}

Test animals were arbitrarily chosen and isolated into four groups meant as control, standard and test tests $(100$ and $200 \mathrm{mg} / \mathrm{kg}$ ) and comprising of 6 mice in every group. This trial depicted by Shoba and Thomas, (2001) [20]. Mice were fasted for $18 \mathrm{~h}$ preceding the test with free access to water. Control (water $5 \mathrm{ml} / \mathrm{kg}$ ), standard (Loperamide $3 \mathrm{mg} / \mathrm{kg}$ ) and test tests $(100$ and $200 \mathrm{mg} / \mathrm{kg}$ ) were managed orally. At that point $1 \mathrm{~h}$ later, $0.3 \mathrm{ml}$ castor oil was regulated orally to every mouse to prompt the runs. Each animal was put in an individual confine, the floor of which was fixed with white smearing paper. The papers were changed each hour. The aggregate quantities of both dry and wet defecation discharged by the animals were noted each hour for a time of $4 \mathrm{~h}$. The aggregate number of diarrheal faeces of the control group was viewed as $100 \%$. Percentage of inhibition of defecation was calculated using the following formula:

\section{Inhibition of defecation $(\%)=$}

Mean No. of defecation by castor oil - Mean No. of defecation by drug or extract

$$
=\frac{\text { Mean No. of defecation caused by castor oil }}{\text { Mat }} \times 100
$$

\section{Magnesium Sulphate-Induced Diarrhea}

The examination was done by technique depicted by Doherty (1981) [21]. Loose bowels was initiated by oral administration of magnesium sulfate at the measurements of $2 \mathrm{~g} / \mathrm{kg}$. The mice were screened and partitioned into various gatherings. Mice were treated with magnesium sulfate ( $2 \mathrm{~g} / \mathrm{kg}$, p.o.) after $30 \mathrm{~min}$ of the administration of the vehicle, medication or concentrates. Subsequent to watching the diarrheal droppings for the following $4 \mathrm{~h}$, the percent (\%) restraint of defecation was computed utilizing a similar equation utilized as a part of castor-oil initiated looseness of the bowels test. 


\section{Statistical Analysis}

The statistical examination for animal trial was completed utilizing one-way ANOVA followed by Dunnett's various correlations. The outcomes got were contrasted with the control group. $\mathrm{P}<0.05$ and $\mathrm{P}<0.001$ were thought to be measurably noteworthy.

\section{Results}

\section{Acute Toxicity}

Oral administration of $C$. appendiculata at the measurements of $500-2000 \mathrm{mg} / \mathrm{kg}$ did not deliver any mortality or perceptible behavioral changes in mice within $72 \mathrm{hr}$ perception period. Accordingly, it can be proposed that $C$. appendiculata have low poisonous quality profile with LD50 more noteworthy than $2000 \mathrm{mg} / \mathrm{kg}$.

\section{Neuropharmacological Activity}

\section{Thiopental Sodium Induced Sleeping Time Test}

In thiopental sodium instigated dozing time test, the concentrate at the measurements of 100 and $200 \mathrm{mg} / \mathrm{kg}$ altogether incited the rest at a prior stage furthermore drawn out the length of dozing time in guinea pigs when contrasted with control (Table 1). The outcome at the dosage of $200 \mathrm{mg} / \mathrm{kg}$ was observed to be measurably huge $(\mathrm{p}<0.001)$. In this test, EECA at the doses of 100 and $200 \mathrm{mg} / \mathrm{kg}$ showed maximum $147.48 \%$ and $195.98 \%$ effect in duration of loss of righting reflex respectively, whereas the standard drug Diazepam $(2 \mathrm{mg} / \mathrm{kg})$ produced 200 percent effect.

Table 1. Effect of EECA on thiopental sodium induced sleeping time test in mice.

\begin{tabular}{|l|c|c|c|c|}
\hline Group & Dose (mg/kg) & $\begin{array}{c}\text { Onset of Sleep } \\
\text { (minutes) }\end{array}$ & $\begin{array}{c}\text { Duration of Sleep } \\
\text { (minutes) }\end{array}$ & Percent effect \\
\hline Control & $5 \mathrm{ml} / \mathrm{kg}$ & $2.06 \pm 0.64$ & $66.33 \pm 8.04$ & 100 \\
\hline Diazepam & 2 & $1.73 \pm 0.20$ & $133 \pm 8.31 *$ & 200.00 \\
\hline \multirow{2}{*}{ EECA } & 100 & $2.47 \pm 0.55$ & $97.83 \pm 14.94$ & 147.48 \\
\cline { 2 - 5 } & 200 & $1.10 \pm 0.21$ & $130 \pm 13.59 * *$ & 195.98 \\
\hline
\end{tabular}

Control group received water $5 \mathrm{ml} / \mathrm{kg}$ (p.o.), standard group received Diazepam $2 \mathrm{mg} / \mathrm{kg}$ body weight (i.p.), test group EECA was treated with 100 and $200 \mathrm{mg} / \mathrm{kg}$ body weight of the extract (p.o.) respectively. Values are mean \pm SEM, $(\mathrm{n}=6) ; * p<0.05, * * p<0.001$, Dunnett t-test as compared to control. EECA=Ethanolic extract of Commelina appendiculata.

\section{Hole Cross Test}

In hole cross test, the EECA demonstrated detectable abatement in the locomotor movement from second perception $(30 \mathrm{~min})$ to fifth perception $(120 \mathrm{~min})$ at the dosages of 100 and $200 \mathrm{mg} / \mathrm{kg}$ which speak to the CNS depressant of the concentrate (Table 2). Most extreme depressant impact was seen from third $(30 \mathrm{~min})$ to fifth $(120 \mathrm{~min})$ perception period. The impact was dose dependent and factually huge $(\mathrm{p}<0.05,0.001)$ compared to control. In hole cross test, maximum $89.02 \%$, and $96.7 \%$ suppression of locomotor activity were exhibited with the EECA at the doses of 100 and $200 \mathrm{mg} / \mathrm{kg}$ respectively. In this study Diazepam (63.42\% suppression) was used as standard. 
Table 2. Effect of EECA on hole cross test in mice.

\begin{tabular}{|c|c|c|c|c|c|c|}
\hline \multirow{2}{*}{ Group } & \multirow{2}{*}{$\begin{array}{c}\text { Dose } \\
\text { (mg/kg) }\end{array}$} & \multicolumn{5}{|c|}{ Number of movements (\% of Number of movements inhibition) } \\
\hline & & 0 min & $30 \mathrm{~min}$ & $60 \mathrm{~min}$ & $90 \mathrm{~min}$ & $120 \mathrm{~min}$ \\
\hline Control & $5 \mathrm{ml} / \mathrm{kg}$ & $15.5 \pm 1.84$ & $14.33 \pm 2.18$ & $13.67 \pm 1.83$ & $10.5 \pm 1.03$ & $10 \pm 1.41$ \\
\hline Diazepam & 2 & $12.83 \pm 2.18$ & $\begin{array}{c}9.83 \pm 1.51 \\
\mathbf{3 1 . 4 0 \%}\end{array}$ & $\begin{array}{c}5 \pm 1.80 * * \\
\mathbf{6 3 . 4 2 \%}\end{array}$ & $\begin{array}{c}4 \pm 1.03 * * \\
\mathbf{6 1 . 9 0 \%}\end{array}$ & $\begin{array}{c}3.67 \pm 1.14 \% \\
\mathbf{6 3 . 3 \%} \%\end{array}$ \\
\hline \multirow{2}{*}{ EECA } & 100 & $8.17 \pm 2.53$ & $\begin{array}{c}4.67 \pm 2.54 * \\
\mathbf{6 7 . 4 1 \%}\end{array}$ & $\begin{array}{c}1.5 \pm 0.48^{* *} \\
\mathbf{8 9 . 0 2 \%} \%\end{array}$ & $\begin{array}{c}2 \pm 0.82 * * \\
\mathbf{8 0 . 9 5 \%}\end{array}$ & $\begin{array}{c}1.67 \pm 0.85^{* *} \\
\mathbf{8 3 . 3 \%}\end{array}$ \\
\hline & 200 & $9 \pm 2.59$ & $\begin{array}{c}2 \pm 0.96^{* *} \\
\mathbf{8 6 . 0 4 \%}\end{array}$ & $\begin{array}{c}0.83 \pm 0.61 * * \\
93.93 \%\end{array}$ & $\begin{array}{c}0.5 \pm 0.56^{* * *} \\
\mathbf{9 5 . 2 3 \%}\end{array}$ & $\begin{array}{c}0.33 \pm 0.24^{* *} \\
\mathbf{9 6 . 7 \%}\end{array}$ \\
\hline
\end{tabular}

Control group received water $5 \mathrm{ml} / \mathrm{kg}$ body weight (p.o.), standard group received Diazepam $2 \mathrm{mg} / \mathrm{kg}$ body weight (i.p.), test group EECA was treated with 100 and $200 \mathrm{mg} / \mathrm{kg}$ body weight of the extract (p.o.) respectively. Values are mean \pm SEM, $(\mathrm{n}=6) ; * p<0.05,{ }^{* *} p<0.001$, Dunnett $t$-test as compared to control. EECA=Ethanolic extract of Commelina appendiculata.

\section{Open Field Test}

The abatement in velocity was likewise obvious from the consequences of open field test. The concentrate delivered dose dependent and measurably critical $(\mathrm{p}<0.05,0.001)$ CNS depressant impact (Table 3). The most extreme impact was seen from third perception (30min) to fifth perception (120 min) period. In open field test, maximum $84.37 \%$, and $90.26 \%$ suppression of locomotor activity were exhibited with EECA (100 and $200 \mathrm{mg} / \mathrm{kg}$ ) respectively, whereas the standard drug Diazepam displayed $65.81 \%$ suppression.

Table 3. Effect of EECA on open field test in mice.

\begin{tabular}{|c|c|c|c|c|c|c|}
\hline \multirow{2}{*}{ Group } & \multirow{2}{*}{$\begin{array}{c}\text { Dose } \\
(\mathbf{m g} / \mathbf{k g})\end{array}$} & \multicolumn{5}{|c|}{ Number of movements (\% of Number of movements inhibition) } \\
\hline & & $\mathbf{0}$ min & $30 \mathrm{~min}$ & $60 \mathrm{~min}$ & 90 min & $120 \mathrm{~min}$ \\
\hline Control & $5 \mathrm{ml} / \mathrm{kg}$ & $112.83 \pm 6.24$ & $112.5 \pm 5.67$ & $103.33 \pm 11.39$ & $99 \pm 3.95$ & $90.67 \pm 1.52$ \\
\hline Diazepam & 2 & $131.33 \pm 7.71$ & $\begin{array}{c}72.67 \pm 17.16^{*} \\
\mathbf{3 5 . 4 0 \%}\end{array}$ & $\begin{array}{c}57 \pm 8.83 * \\
\mathbf{4 4 . 8 4 \%}\end{array}$ & $\begin{array}{c}53 \pm 14.94 * \\
\mathbf{4 6 . 4 6 \%}\end{array}$ & $\begin{array}{c}31 \pm 13.61 * * \\
\mathbf{6 5 . 8 1 \%}\end{array}$ \\
\hline \multirow{2}{*}{ EECA } & 100 & $52.83 \pm 11.37$ & $\begin{array}{c}41.17 \pm 18.62 * \\
\mathbf{6 3 . 4 0 \%}\end{array}$ & $\begin{array}{c}34.17 \pm 14.65^{* *} \\
\mathbf{6 6 . 9 3 \%}\end{array}$ & $\begin{array}{c}35.17 \pm 10.89^{* *} \\
\mathbf{6 4 . 4 7 \%}\end{array}$ & $\begin{array}{c}14.17 \pm 1.77^{* *} \\
\mathbf{8 4 . 3 7 \%}\end{array}$ \\
\hline & 200 & $51.5 \pm 10.81$ & $\begin{array}{c}17.67 \pm 7.88^{* *} \\
\mathbf{8 4 . 2 9 \%}\end{array}$ & $\begin{array}{c}15.83 \pm 6.05^{* *} \\
\mathbf{8 4 . 6 8 \%}\end{array}$ & $\begin{array}{c}11 \pm 3.40 * * \\
\mathbf{8 8 . 8 8 \%}\end{array}$ & $\begin{array}{c}8.83 \pm 3.10^{* *} \\
\mathbf{9 0 . 2 6 \%}\end{array}$ \\
\hline
\end{tabular}

Control group received water $5 \mathrm{ml} / \mathrm{kg}$ body weight (p.o.), standard group received Diazepam $2 \mathrm{mg} / \mathrm{kg}$ body weight (i.p.), test group EECA was treated with 100 and $200 \mathrm{mg} / \mathrm{kg}$ body weight of the extract (p.o.) respectively. Values are mean \pm SEM, $(\mathrm{n}=6) ; * p<0.05, * * p<0.001$, Dunnett $t$-test as compared to control. EECA=Ethanolic extract of Commelina appendiculata.

\section{Antidiarrheal Activity}

\section{Castor Oil-Induced Diarrhea}

In the antidiarrheal action, the extract showed noteworthy $(\mathrm{p}<0.001)$ and a dose dependent reduction in the aggregate number of fecal dropping in castor oil incited the runs in mice. The percentage of inhibition of castor oil-induced diarrhoea in the extract-treated mice was $74.64 \%$ and 
$90.64 \%$ at the doses of 100 and $200 \mathrm{mg} / \mathrm{kg}$ respectively. In this study standard drug Loperamide $(3 \mathrm{mg} / \mathrm{kg}$ ) produced $54.64 \%$ inhibition of defecation.

Table 4. Effects of EECA on castor oil-induced diarrhea in mice.

\begin{tabular}{|l|c|c|c|}
\hline Group & Dose $\mathbf{( m g / \mathbf { k g } )}$ & No. of faeces in $\mathbf{4 h r}$ & \% Inhibition of defecation \\
\hline Control & $5 \mathrm{ml} / \mathrm{kg}$ & $12.5 \pm 1.56$ & --- \\
\hline Loperamide & 3 & $5.67 \pm 1.40^{*}$ & 54.64 \\
\hline \multirow{2}{*}{ EECA } & 100 & $3.17 \pm 1.51 * *$ & 74.64 \\
\cline { 2 - 4 } & 200 & $1.17 \pm 0.67 * *$ & 90.64 \\
\hline
\end{tabular}

Control group received water $5 \mathrm{ml} / \mathrm{kg}$ (p.o.), standard group received Loperamide $3 \mathrm{mg} / \mathrm{kg}$ body weight (p.o.), test group EECA was treated with 100 and $200 \mathrm{mg} / \mathrm{kg}$ body weight of the extract (p.o.) respectively. Values are mean \pm SEM, $(\mathrm{n}=6) ; * p<0.05, * * p<0.001$, Dunnett t-test as compared to control. EECA=Ethanolic extract of Commelina appendiculata.

\section{Magnesium Sulphate-Induced Diarrhea}

In magnesium sulfate-prompted diarrhea, the concentrates demonstrated a dose dependent diminishment in fecal dropping in a comparative way like in castor oil-initiated loose bowels (Table 5). Critical $(\mathrm{p}<0.001)$ diminishment in fecal dropping was appeared by the ethanol extract at $200 \mathrm{mg} / \mathrm{kg}(80.95 \%)$ measurements. At $100 \mathrm{mg} / \mathrm{kg}$ measurement likewise demonstrated $65.00 \%$ hindrance of diarrheal droppings, $(\mathrm{p}<0.001)$.

Table 5. Effects of EECA on magnesium sulphate-induced diarrhoea in mice.

\begin{tabular}{|l|c|c|c|}
\hline Group & Dose (mg/kg) & No. of faeces in $\mathbf{4 h r}$ & \% Inhibition of defecation \\
\hline Control & $5 \mathrm{ml} / \mathrm{kg}$ & $10.5 \pm 0.92$ & -- \\
\hline Loperamide & 3 & $5.16 \pm 1.22 *$ & 50.85 \\
\hline \multirow{2}{*}{ EECA } & 100 & $4 \pm 1.35 * *$ & 65.00 \\
\cline { 2 - 4 } & 200 & $2 \pm 0.57 * *$ & 80.95 \\
\hline
\end{tabular}

Control group received water $5 \mathrm{ml} / \mathrm{kg}$ (p.o.), standard group received Loperamide $3 \mathrm{mg} / \mathrm{kg}$ body weight (p.o.), test group EECA was treated with 100 and $200 \mathrm{mg} / \mathrm{kg}$ body weight of the extract (p.o.) respectively. Values are mean \pm SEM, $(\mathrm{n}=6) ; * p<0.05,{ }^{* *} p<0.001$, Dunnett t-test as compared to control. EECA= Ethanolic extract of Commelina appendiculata.

\section{Discussion}

It is normally acknowledged that the sedative impacts of drugs can be assessed by estimation of pentobarbitone sleeping time in laboratory animals [22, 23]. Prolongation of pentobarbitoneinitiated mesmerizing is suggestive of central depressant movement of a compound [24]. The impact on the CNS of the EECA $(200 \mathrm{mg} / \mathrm{kg})$ were delivered a critical $(\mathrm{p}<0$ 0.001) increment in the mesmerizing impact initiated by the phenobabitone, in a dose dependent way, in this manner proposing a profile of sedative action. Locomotor action considered as an expansion in readiness and lessening in locomotor action showed sedative effect [25]. In hole cross and open field test, the extract demonstrated discernible diminishing in the locomotor action from second perception (30 $\mathrm{min})$ to fifth perception $(120 \mathrm{~min}$ ) at the measurements of 100 and $200 \mathrm{mg} / \mathrm{kg}$ which speak to the CNS depressant of the extract (Table 2 and 3). Greatest depressant impact was seen from third (30 $\mathrm{min})$ to fifth $(120 \mathrm{~min})$ perception period. The impact was dose dependent and statistically noteworthy $(\mathrm{p}<0.05,0.001)$ contrasted with control. In hole cross test, most extreme $89.02 \%$ and $96.70 \%$ concealment of locomotor movement were shown with the dosages of 100 and $200 \mathrm{mg} / \mathrm{kg}$ of EECA, separately. In this study, Diazepam (63.3\%) was utilized as standard. In open field test, greatest $84.37 \%$ and $90.26 \%$ concealment of locomotor action were shown with the measurements 
of 100 and $200 \mathrm{mg} / \mathrm{kg}$ of CA individually, while the standard medication Diazepam created $65.81 \%$ concealment. Concentrate of CA diminished locomotor action shows its CNS depressant action. Gamma-amino-butyric acid (GABA) is the major inhibitory neurotransmitter in the central nervous system. Diverse anxiolytic, muscle relaxant, narcotic trancelike medications are clarification their activity through GABAA, subsequently it is conceivable that concentrate of C.appendiculata may acts by potentiating GABAergic hindrance in the CNS by means of membrane hyperpolarization which prompts to a diminishing in the firing rate of basic neurons in the mind or might be because of direct enactment of GABA receptor by the concentrate [26]. Many research demonstrated that plant containing flavonoids, saponins and tannins are helpful in numerous CNS issue [27]. Prior examination on phytoconstituents and plants proposes that numerous flavonoids and neuroactive steroids were observed to be ligands for the GABAA receptors in the central nervous system, which prompted to the accept that they can go about as benzodiazepine like molecules [25]. Tannins have additionally been accounted for to demonstrate non-particular CNS discouragement in mice [28]. Phytochemical examinations likewise demonstrated the presence of alkaloids, flavonoids, sugars and tannins in EECA [5]. So may be this phytoconstituents are in charge of its CNS depressant movement. The restraint of loose bowels in mice, initiated by castor oil and magnesium sulfate, is utilized to decide the antidiarrheal action of plant extracts. Castor oil fortifies the arrival of prostaglandin $\mathrm{E}$ in the colon [29], diminishes $\mathrm{Na}+, \mathrm{K}+$ ATPase movement [30], and adjusts the intestinal histology and penetrability [31]. These decrease or reverse absorption of water and electrolytes from the intestinal lumen and colon and cause secretory loose bowels in mice. Magnesium sulfate causes expanded loss of intestinal substance because of the lessening in reabsorption of water and cholecystokinin discharge from the duodenal mucosa. These expansion the secretion and motility of small intestine, keep the reabsorption of sodium chloride and water, and instigate diarrhea [32, 33]. In this study, the concentrates demonstrated a dose dependent diminishment in fecal droppings in both castor oil-and magnesium sulfate-prompted looseness of the bowels (Table 4 and 5). Tannins may grant antidiarrheal impact potentially by hindering the intestinal motility [32] and diminishing the intestinal secretion [34]. It might be conceivable that the antidiarrheal movement is because of the tannins [35], alkaloids [36], glycosides [37] and different phytoconstituents.

\section{Conclusion}

The consequences of the present study shows the anti-diarrhoeal and CNS depressant action of $C$. appendiculata which deserve further studies to build up its helpful esteem and additionally its mechanism of action.

\section{Competing Interests}

The authors declare that they have no competing interests.

\section{Authors' Contributions}

All authors are equally contributed.

\section{Acknowledgments}

The authors are acknowledge to the director of Animal Research Division of the International Centre for Diarrhoeal Disease and Research, Bangladesh (ICDDR, B) for supplying mice and Jahangirnagar University Herbarium for identifying the plant sample. 


\section{References}

[1] K.U. Siddique et al., Encyclopedia of flora and fauna of Bangladesh. Angiosperms: Monocotyledons (Agavaceae-Najadaceae), Asiatic Society of Bangladesh, Dhaka. 11 (2007) 145 .

[2] P.G. Xiao, New edited records of Traditional Chinese Medicine, Chemical Industry Press, Beijing, vol. 3, 2003.

[3] X.Y. Tang, M.H. Zhou, Y.B. Zhang, Active constituents of Commelina communis L, China Journal of Chinese Materia Medica. 19(5) (1994) 297-298.

[4] O.K. Kim et al., Screening of edible Japanese plants for nitric oxide generation inhibitory activities in RAW 264.7 cells, Cancer Letters. 125 (1998) 199-207.

[5] P.R. Dash, M.S. Rana, M.S. Ali, Investigation of analgesic and cytotoxic activities of ethanol extract of Commelina appendiculata, J. Pharmacogn. Phytochem. 4(3) (2015) 53-59.

[6] S.C. Sharma, T J.S. Andon, A dammarane triterpene from Commelina undulata, Phytochemistry. 21 (1982) 2420-2421.

[7] J.Z. Stirton, J.B. Harborne, Two distinctive anthocyanin patterns in the commelinaceae, Biochem. Syst. Ecol. 8(3) (1980) 285-287.

[8] Botanical Institute of Jiangsu Province, Compendium of Xinhua Materia Medica, 2nd ed., Vol. II. Scientific and Technological Press of Shanghai, 1991, p. 574.

[9] M. Shiono, N. Matsugaki, K. Takeda, Structure of commelinin, a blue complex pigment from the blue flowers of Commelina communis, Proceedings Japan Acad. Series B. 84(10) (2008) $52-56$.

[10] T. Goto et al., The real anthocyanin present in blue-colored flower petals of Commelina communis, Tetrahedron Lett. 24 (1983) 4863-4866.

[11] T. Hondo et al., Structural basis of blue-colour development in flower petals from Commelina communis, Nature. 358 (1992) 515-518.

[12] X.Y. Tang, M.H. Zhou, Y.B. Zhang, Active constituents of Commelina communis L., China J. Chin. Mater. Med. 19 (1994) 297-298.

[13] Q. Yang, G. Ye, A new C-glucoside from Commelina communis, Chem. Nat. Comp. 45 (2009) 59-60.

[14] Q. Yang, G. Ye, W.M. Zhao, Chemical constituents of Commelina communis Linn, Biochem. Syst. Ecol. 35(9) (2007) 621-623.

[15] M.S. Ali, P.R. Dash, M. Nasrin, Study of sedative activity of different extracts of Kaempferia galangal in Swiss albino mice, BMC Complement Altern. Med. 15 (2015) 158.

[16] C.I. Walker et al., Antinociceptive activity of Mirabilis jalapa in mice, J. Ethnopharmacol. $120(2008)$ 169-175.

[17] R.A. Turner, Screening methods in pharmacology, New York and London, Academic Press, 1965, pp. 64-69.

[18] K. Takagi, M. Watanabe, H. Saito, Studies on the spontaneous movement of animals by the hole cross test: Effect of 2-dimethylaminoethan its acylesters on the central nervous system, The Japanese Journal of Pharmacology. 21(6) (1971) 797-810.

[19] B.D. Gupta, P.C. Dandiya, M.L. Gupta, A psychopharmacological analysis of behaviour in rat, The Japanese Journal of Pharmacology. 21(3) (1971) 293-298.

[20] S.F.G. Hoba, M. Thomas, Study of antidiarrhoeal activity of four medicinal plants in castoroil induced diarrhea, J. Ethnopharmacol. 76 (2001) 73-76. 
[21] N.S. Doherty, Inhibition of arachidonic acid release as the mechanism by which glucocorticoids inhibit endotoxin-induced diarrhea, Br. J. Pharmacol. 73 (1981) 549-554.

[22] M.C. Lu, Studies on the sedative effects of Cistanche deserticola, J. Ethnopharmacol. 59 (1998) 161-165.

[23] K. Gamaniel et al., Pharmacological profile of NIPRD 94/002/1 - 0. A novel herbal antisickling agent, J. Pharmaceut. Res. Dev. 3(2) (1998) 89-94.

[24] R.M.G. Perez et al., Neuropharmacological activity of Solanum nigrum fruit, J. Ethnopharmacol. 62 (1998) 43-48.

[25] A. Verma et al., Pharmacological evaluation of Saraca indica Leaves for central nervous system depressant activity in mice, J. Pharm. Sci. Res. 2(6) (2010) 338-343.

[26] O.T. Kolawole, J.M. Makinde, O.A. Olajide, Central nervous depressant activity of Russelia equisetiformis, Niger. J. Physiol. Sci. 22(1-2) (2007) 59-63.

[27] S.K. Bhattacharya, K.S. Satyan, Experimental methods for evaluation of psychotropic agents in rodents: I--Anti-anxiety agents, Indian J. Exp. Biol. 35 (1997) 565-575.

[28] R.N. Takahashi, T.C. de Lima, G.S. Morato, Pharmacological action of tannic acid; II. Evaluation of CNS activity in animals, Planta Med. 52 (1986) 272-275.

[29] E. Beubler, H. Juan, Effect of ricinoleic acid and other laxatives on net water flux and prostaglandin E release by the rat colon, J. Pharm. Pharmacol. 31 (1979) 681-685.

[30] T.S. Gaginella, S.F. Phillips, Ricinoleic acid: Current view of an ancient oil, Am. J. Dig. Dis. 20 (1975) 1171-1177.

[31] N. Mascolo et al., Inhibitors of nitric oxide synthetase prevent castor-oil-induced diarrhoea in the rat, Br. J. Pharmacol. 108 (1993) 861-864.

[32] J. Gálvez et al., Antidiarrhoeic activity of Sclerocarya birrea bark extract and its active tannin constituent in rats, Phytother. Res. 5 (1991) 276-278.

[33] S.J. Uddin et al., Antidiarrhoeal activity of the methanol extract of the barks of Xylocarpus moluccensis in castor oil- and magnesium sulphateinduced diarrhoea models in mice, J. Ethnopharmacol. 101 (2005) 139-143.

[34] P.K. Mukherjee et al., Antidiarrhoeal evaluation of Nelumbo nucifera rhizome extract, Indian J. Pharmacol. 27 (1995) 262-264.

[35] A. Agunu et al., Evaluation of five medicinal plants used in diarrhoea treatment in Nigeria, J. Ethnopharmacol. 101 (2005) 27-30.

[36] S. Mandal et al., Antidiarrhoeal activity of carbazole alkaloids from Murraya koenigii Spreng (Rutaceae) seeds, Fitoterapia. 81 (2010) 72-74.

[37] T.A. Abere, P.E. Okoto, F.O. Agoreyo, Antidiarrhea and toxicological evaluation of the leaf extract of Dissotis rotundifolia Triana (Melastomataceae), BMC Complement Altern. Med. 10(1) (2010) 71. 